\title{
4. Minority Religious Identity and Religious Social Distance in Australia ${ }^{1}$
}

\author{
Gary D. Bouma
}

Australia's early colonial history was one of religious freedom and an absence of religious discrimination. Anglicans enjoyed a comfortable dominance due to their state church position in England, but in Australia Anglican establishment was never enacted in law. From about 1830 local officials and governments made room for other religious groups and provided them state support (Carey 1996; Fletcher 2002). From first European settlement in 1788 through to the late twentieth century, Anglicans, Presbyterians, Methodists, other Protestants, Catholics, Jews - and, later, Orthodox and some Muslims - mostly cooperated in the development of a new nation. These settlers and their families were distanced both socially and geographically from the religious powers, conflicts and prejudices of Britain and Europe. Most Australians mixed with people of other religions in school, work and leisure and religious identity was deemphasised (Carey 1996; Levi 2006; Levi and Bergman 2002). This basic pattern has continued to the present as religious diversity in Australia has increased substantially since 1947 due primarily to migration (Bouma 2006).

To be sure, religious identity was never insignificant in Australian inter-group relations. Religious groups' differences were expressed in differences in family lifestyles, education, politics, ethics and even sporting loyalties (Bouma and Dixon 1986). Recognition of religious identity differences patterned forms of religious exclusiveness and inter-religious suspicions and sectarian rivalries (Hogan 1987). Social cohesion, though, was never threatened. Australians have developed an overriding identity in their nationalism, which has been associated with the norms of fairness for people of differing backgrounds, and general 'mateship'.

This context has been challenged since the late 1960s, when Australia began accepting significant numbers of migrants from outside Europe. Religious diversity has become broader and more complex, with significant and growing minorities of Buddhists, Muslims and Hindus. Australia also has a broader range of Christian denominations, new religious movements and 'nature' religions (Bouma 2006; Cahill et al. 2004). Indigenous religions, while small in number, are also recognised now (Bell 2009).

1 An earlier version of this chapter was presented to the annual meetings of the Society for the Scientific Study of Religion, Louisville, Kentucky. The author wishes to acknowledge his indebtedness to Dr Rodney Ling who provided much needed assistance in analysing the data. 
Australia's social cohesion continues to allow much equality and nondiscrimination. Muslims, Buddhists, Hindus and other religious groupsparticularly those expanding significantly-are integrating into everyday Australian society and achieving in education, the arts, business, public service and politics (Jupp, Niewenhuysen and Dawson 2007; Markus 2008, 2009, 2010). Integration has not, however, always been smooth as certain groups, particularly Muslims, have been singled out in public as 'others' whose difference is too great or as a religious group to be feared (Bouma et al. 2011; Deen 2009). While in the mid-1990s concern was expressed about coping with Asian migration, following the events of 11 September 2001, Muslims have been the focus of concern (Bouma et al. 2006). In recent years there have been notable incidents of religious-based tension, exclusion and, in some reported cases, violence (HREOC 2004). It is timely to consider how particular religious groups are regarded among Australians, and the implications for Australia's social cohesion.

Using data from the Australian Survey of Social Attitudes (AuSSA), a large biannual public survey, this chapter examines differences in attitudes among Australia's largest and most consolidated religious groups - Catholics, Anglicans, Uniting, Presbyterians - towards a set of minority religious groups: Greek Orthodox, Buddhists, Born Again Christians, Hindus, Jews, Jehovah's Witnesses and Muslims. The degree of welcome or feelings of distance towards particular minority religious groups is interesting in itself; however, since some challenges to religious inter-group relations have historically been generated by religious differences (Appleby 2000) and appear to be today as well in Australia (Bouma et al. 2011), the sentiments of several religious groups towards other religious groups are compared.

Those declaring that they had 'no religion' have been excluded from the analysis as the group lacks sufficient internal defining consistency beyond this denial. Moreover, its range of attitudes towards religious groups was understandably negative towards both major and minority groups. They were over-represented among those least welcoming to the majority groups, in the mid-range among those not welcoming Muslims, Hindus and Jews, and least welcoming of the 'born again'.

\section{The data}

The data were taken from a 'module' or stage of the 2007 AuSSA. Total respondents for the module numbered 2769. Respondents were randomly selected from the electoral roll and the survey was administered by mail. This particular module included a set of Bogardus social distance scales (Bogardus 1925, 1933, 1947), measuring respondents' preferred degrees of social distance 
from people from a range of religious groups. The Bogardus social distance scales continue to be used in studies of inter-group relations (Dietrich et al. 2004; Parrillo and Donoghue 2005).

This chapter will use a sub-sample from the 2007 survey - those respondents who identified with one of Australia's major religious groups: Anglican, Catholic, Uniting Church and Presbyterian. Other religious groups lacked sufficient numbers for meaningful statistical analysis and were not able to be grouped into meaningful subgroups. This sub-sample totalled 1500, with Catholics the largest group at 657 or 43.8 per cent, Anglicans at 556 or 37.1 per cent, Uniting 204 or 13.6 per cent and Presbyterian and Reformed at 83 or 6.5 per cent. On most characteristics the distribution of the sub-sample closely mirrors the 2006 Australian Census percentage portions, when persons aged under eighteen are omitted.

\section{Social distance scale responses: Description and basic results}

Respondents were asked to specify the level of social distance they would prefer to members of the following religious groups: Anglican, Born Again Christian, Buddhist, Catholic, Greek Orthodox, Hindu, Jehovah's Witness, Jew and Muslim. Responses to Anglicans and Catholics were omitted from analysis as these groups are not minority groups and enjoyed very high levels of acceptability in comparison with the minority religious groups.

The following Bogardus social distance scale (BSDS) responses were offered for each group: 'How close are you prepared to be with Muslims, etc?'

1. family member

2. close friend

3. next-door neighbour

4. workmate

5. fellow Australian citizen

6. foreign visitor only

7. should keep out of Australia altogether

8. don't know. 
Bogardus (1947) argued on the basis of extensive research using more than 60 scale items that these items represented equidistant points on the social distance scale.

\section{Reliability}

As stated above, this analysis uses data from BSDS responses relating to Greek Orthodox, Buddhists, Born Again Christians, Hindus, Jews, Jehovah's Witnesses and Muslims. Since analysis of the responses to the BSDS will include comparisons of the BSDS responses with each of the religious groups, a calculation of scale reliability is appropriate. Cronbach's alpha provides an assessment of the internal consistency of a scale through an average correlation of the items in a survey comprising the scale. Cronbach's alpha across all the above BSDSs, for respondents who answered all BSDSs $(\mathrm{n}=1297)$, was 0.950, which would be lowered by the deletion of any item.

\section{Analysis}

As stated above, the respondents are those from the 'most established' religious institutions in Australia: Anglican Church, Catholic Church, Uniting Church and Presbyterian Church. These groups also are sufficiently numerous to generate meaningfully and useably large samples for statistical analysis. Analysis will examine each of these groups' responses to BSDSs for a set of 'religious minorities': Greek Orthodox, Buddhists, Born Again Christians, Jews, Hindus, Jehovah's Witnesses and Muslims.

In Australian society today, these 'religious minorities' carry varied qualities of social meaning. Hindus, Buddhists and Muslims have grown very significantly since the 1960s and 1970s and would generally be labelled as 'significant' minority religious communities. Their growth reflects major cultural changes in Australia away from the old hegemony of Catholicism and British Protestantism. This is reflected in the fact that as of 2006 there were more Buddhists than Baptists, more Muslims than Lutherans and twice as many Hindus as Jews in Australia (Bouma 2006). Jews have been publicly practising in Australia since early European settlement, and until the 1960s and 1970s were the country's only significant and socially accepted 'religious minority' (Levi 2006). In the religiously diverse society of the present though, Jews represent an established 'old minority' in contrast with the growing 'new minorities' of Hindus, Buddhists and Muslims. 


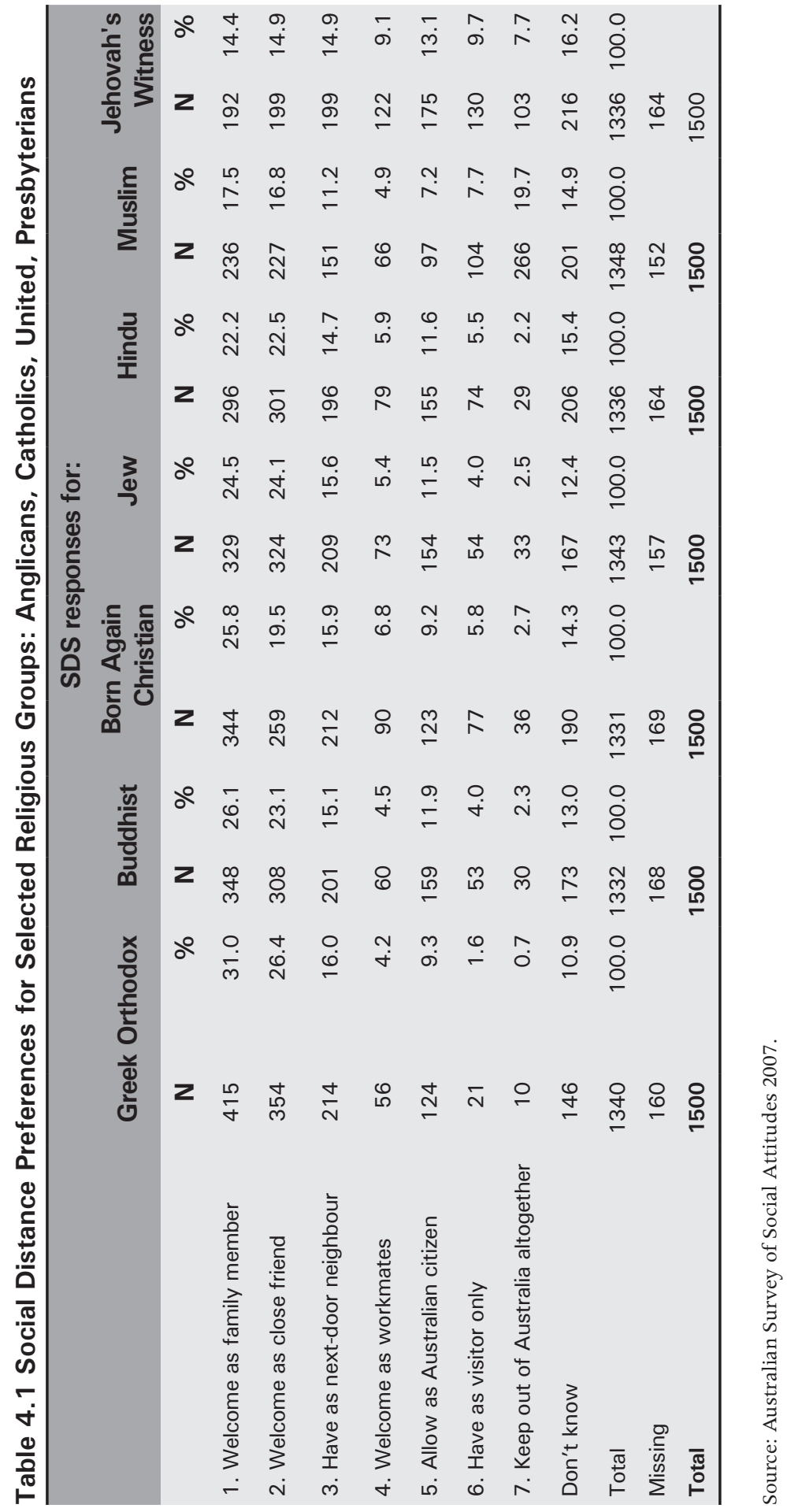


The term 'Born Again Christians' does not apply to a specific denomination. Rather, it refers to Christians with vigorous re-found faith. Born Again Christians may identify with any Protestant denomination, but they are probably associated most with evangelical and growing Pentecostal groups outside the main denominations (Hutchinson 2009; Piggin 2009). In Australia, Jehovah's Witnesses are a small but viable Christian denomination, considered 'marginal' due to special beliefs and practices that offend Australian norms on respect for personal space, religious belief and military service (Jupp 2009a, 342-5). In contrast with Jews, Jehovah's Witnesses have not come to be viewed as an established or accepted religious minority.

Table 4.1 presents the absolute responses for each religious group. The Greek Orthodox attracts the greatest percentage BSDS scores in the category of closest social distance, 'Welcome as a family member'. This is not surprising as Greek Orthodox churches have operated in Australia for about a century and Greeks are a significant and integrated ethnic group, highly associated with postWorld War II migration (Jupp 2001; Tamis 2009). When response categories one ('Welcome as a family member') and two ('Welcome as close personal friend') the categories of closest social distance-are combined, 57.4 per cent of the respondents 'welcomed' Greek Orthodox in this way.

For response category one, scores were close on scales for Buddhists, Born Again Christians, Jews and Hindus respectively at 26.1 per cent, 25.8 per cent, 24.5 per cent and 22.2 per cent. Also, each of these religious groups had more than 40 per cent of BSDS responses in categories one and two. Given the closeness of scores on BSDS responses for these groups, they will be considered as together occupying the second-highest level of social closeness. Combined percentages for the two most distant response categories - 'Have as visitors only' and 'Keep out of Australia' - were also similar across the BSDS responses for these groups: Buddhists, 6.3 per cent; Born Again Christians, 8.5 per cent; Jews, 6.5 per cent; and Hindus, 7.7 per cent.

Respondents wanted greatest social distance from Muslims and Jehovah's Witnesses. These groups had the lowest percentage BSDS category one responses at 17.5 and 14.4 per cent, respectively. Combined, scores in categories one and two were 34.4 per cent for Muslims and 29.3 per cent for Jehovah's Witnesses. Moreover, almost one-fifth or 19.7 per cent of respondents considered that Muslims should 'keep out of Australia altogether', compared with the comparatively high but lower 7.7 per cent for Jehovah's Witnesses. Muslims may be identified by significant numbers of respondents primarily as undesirable migrants while Jehovah's Witnesses are seen as Australians with an undesirable religion. 
According to the BSDS responses to the questions, the religious groups fell into three levels of social acceptance from most accepted to least. Australians who identified as Anglican, Catholic, Uniting or Presbyterian found: 1) Greek Orthodox most acceptable; 2) Buddhists, Born Again Christians, Jews and Jehovah's Witnesses in the next level of acceptance; and 3) Jehovah's Witnesses and Muslims least acceptable.

\section{Assessing religious differences in religious social distance}

In order to compare the responses of respondents from different religious groups BSDS scores were calculated for each religious group using the ordinal codes of response categories (see Table 4.2). This follows the usual practice for the analysis of BSDS data (see Bogardus 1947; Thyne and Lawson 2001). For this analysis, respondents who chose the category '8-Don't Know' are omitted. This response category lies outside the incremental plane of social distance described by the other response values. Inclusion of respondents who chose '8-Don't know' would inflate mean values without a clear meaning to the shift, which could be mistakenly interpreted as preference for a greater level of social distance. Unfortunately this lowered the valid response rate across scales. Chronbach's alpha still showed high reliability at 0.935 , which would have been lowered with the exclusion of any BSDS item.

Table 4.2 Anglicans, Catholics, United, Presbyterians: Mean social distances for religious groups

\begin{tabular}{lrrrrr}
\hline \multicolumn{1}{c}{ Scale: 1 (closest) to 7 (most distant) } \\
\multicolumn{1}{c}{ SDS from: } & Valid $\mathbf{n}$ & $\begin{array}{c}\text { Sample } \\
\text { mean }\end{array}$ & $\begin{array}{c}\text { Std error } \\
\text { of mean }\end{array}$ & $\begin{array}{c}\text { Lonfidence } \\
\text { interval }\end{array}$ \\
& 1194 & 2.35 & 0.041 & 2.27 & Upper \\
\hline Greek Orthodox & 1159 & 2.70 & 0.049 & 2.60 & 2.80 \\
Buddhists & 1176 & 2.74 & 0.049 & 2.64 & 2.83 \\
Jews & 1141 & 2.79 & 0.051 & 2.69 & 2.89 \\
Born Again Christians & 1130 & 2.85 & 0.051 & 2.75 & 2.95 \\
Hindus & 1120 & 3.62 & 0.058 & 3.50 & 3.73 \\
Jehovah's Witnesses & 1147 & 3.82 & 0.068 & 3.68 & 3.95 \\
Muslims & & & & &
\end{tabular}

Source: Australian Survey of Social Attitudes 2007. 
Table 4.2 presents the mean BSDS response to each of the 'target groups' for this sample of those who identified as Catholic, Anglican or Presbyterian/Reformed. The numbers in the column 'Valid n' can be verified by subtracting the 'Don't know' responses for each scale in Table 4.2. This descriptive analysis is sensibly consistent with Table 4.1. The higher the mean BSDS score, the greater is the level of social distance preferred, or the lower is the degree of acceptance. There are basically three levels for which the sample preferred progressively greater social distance: 1) Greek Orthodox-least; 2) Buddhists, Jews, Born Again Christians, Hindus - moderate; 3) Jehovah's Witnesses and Muslims-most. The 95 per cent confidence intervals for the SDSs with the lowest and secondlowest means, Greek Orthodox and Buddhists, do not intersect, indicating that there is a clear difference between the mean BSDS responses for these groups, with the Greek Orthodox being lower - that is, more acceptable. The confidence intervals of scores for Buddhists, Jews, Hindus and Born Again Christians, however, intersect and thus these groups can be classified as a range of religions with the second-lowest set of means, or a group which received the second level of acceptance receiving the second-closest set of social distance preferences. Jehovah's Witnesses and Muslims have means with confidence intervals that are clearly higher as their confidence intervals do not overlap with those groups with lower scores and are hence the least accepted of the groups considered.

The analysis is guided by a single research question: to what extent do major religious groups in Australia-Anglican, Catholic, Uniting and Presbyterian/ Reformed-differ in their social distance preferences for Greek Orthodox, Buddhists, Born Again Christians, Hindus, Jehovah's Witnesses and Muslims. To assess whether associations exist between religious identification and the BSDS responses for each of the religious groups considered, two basic statistical tests were used. First, independent sample t-tests were administered to compare mean scores of categories for independent variables with only two response categories. Second, one-way ANOVA tests were applied where independent variables had three or more categories. The post-hoc test used with the ANOVA was the Scheffe test, chosen because it is appropriate for unequal sample sizes (Jones 2008). The Scheffe test indicates whether there are significant differences between the means of response categories of the independent variable, using a formula similar to an F-test. 


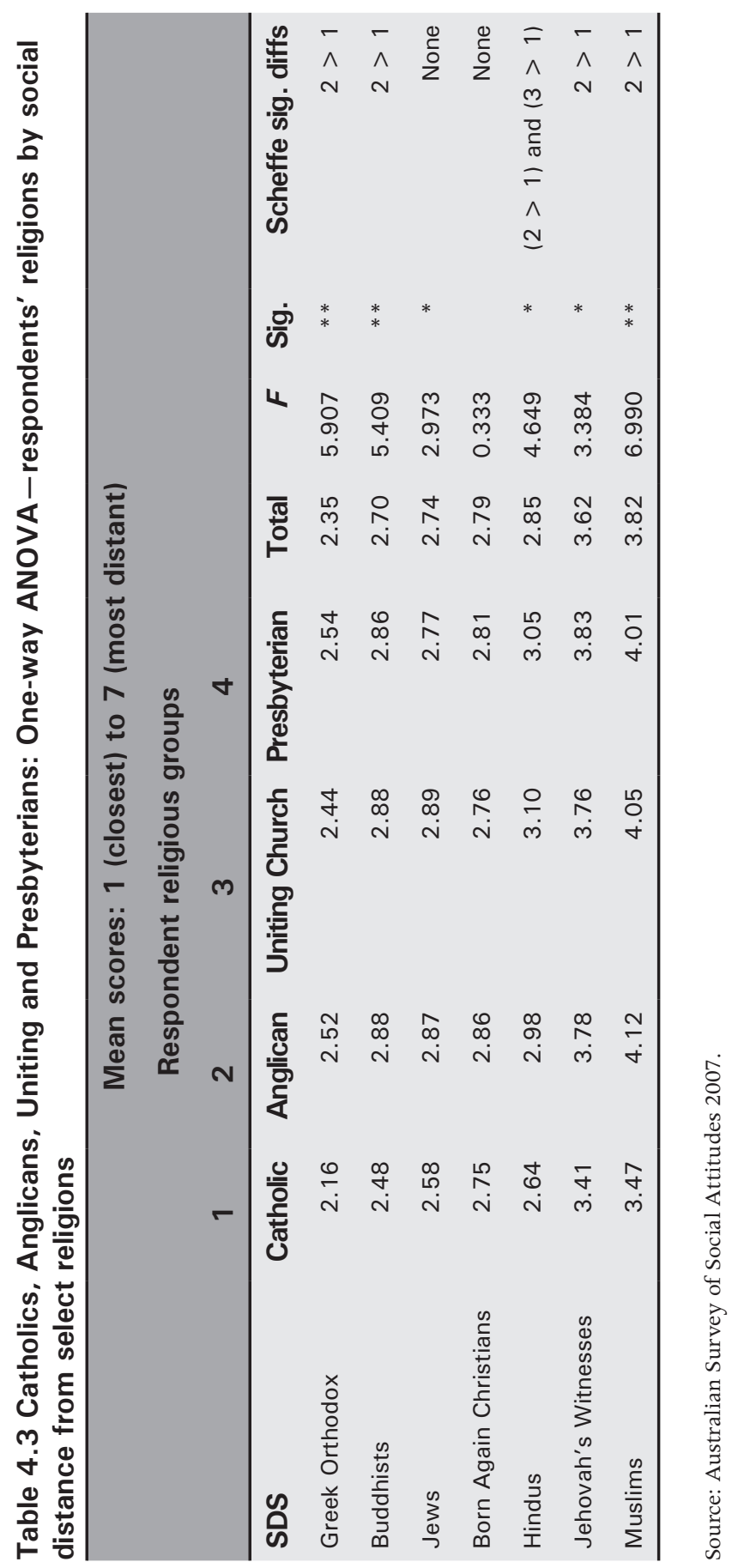




\section{Religious identity and religious social distance}

The one-way ANOVA analysis presented in Table 4.3 reveals that differences in respondents' religious identity across BSDS responses were statistically significant with the exception of responses to Born Again Christians. Scheffe tests revealed the following patterns: 1) except for the BSDS responses to Jews and Born Again Christians, the means of Catholic respondents are significantly lower (more accepting) than those from Anglicans; 2) Uniting Church respondents' mean BSDS responses for Hindus were significantly higher (less accepting) than Catholics. ${ }^{2}$ The greatest difference was the statistically significant higher BSDS response from Anglicans in comparison with the more accepting Catholics. From this result the conclusion is drawn with substantial confidence that Catholics are more tolerant of inter-religious difference than Anglicans.

\section{Discussion}

This analysis of religious social distance preferences used nationally representative data provided by respondents from Australia's largest and most consolidated religious identities: Anglicans, Catholics, Uniting and Presbyterians. Responses to Bogardus social distance scales indicated that people who identify with these religious groups were prepared to be socially closest to Greek Orthodox; secondclosest to Buddhists, Jews, Born Again Christians and Hindus; and that they preferred to be most distant from Jehovah's Witnesses and Muslims.

Respondents were most likely to prefer greater social distance from Jehovah's Witnesses and Muslims. As a larger percentage of respondents wanted Muslims to 'keep out of the country altogether', the negative response to Muslims is possibly a reaction to both their religion and the fact that they are a migrant group. This, however, is equally true of Buddhists and even more so of Hindus, both of whom are religiously different and most of whom are migrants. Thus, it would appear that the significantly greater negative reaction is to Muslims as a religious group rather than as a migrant group. This is made all the more likely by the fact that there are groups in Australia who actively campaign to limit, reduce or eliminate Muslim migration (Bouma et al. 2011 70-2, 81).

\footnotetext{
2 Post-hoc tests, including the Scheffe, have anomalies. For example, when comparing the mean responses to the Greek Orthodox, the mean social distance scale response of those identifying with the Uniting Church is not significantly different from Anglican or Catholic, but the mean social distance scale response of Anglicans is significantly greater than that for Catholic respondents. The anomalies can be understood as a consequence of comparing categories with populations of significantly different sizes. Categories with lower populations have larger standard errors of the mean, and so the 95 per cent confidence intervals of their means are likely to be wider, and have greater chance of overlapping with other categories. The standard errors of the means of larger population give narrower 95 per cent confidence intervals, increasing the chance that when compared with other categories, they will be different.
} 
Comparisons with earlier attempts to assess religious social distance in Australia indicate a softening of negative attitudes towards Muslims over the past two decades. In a 1988 national survey conducted by the Office of Multicultural Affairs (OMA 1989) 32 per cent of Australians responded 'Visitor only' or 'Keep out' to Muslims compared with 24 per cent in this sample taken in 2007. This softening is also seen for responses to other groups. In 1988, 26 per cent responded in these two most negative response categories to Buddhists, while in this 2007 survey it was 5.4 per cent. Similarly, in 1988, 12 per cent responded in this way to Jews compared with 6.2 per cent in 2007.

Thus, in a context of increasing acceptance of religious diversity and seen by the greater acceptance of particular religious groups into Australian society and into the domestic lives of Australians, Muslims have progressed towards full acceptance more slowly than Buddhists and Jews. An outstanding finding from this analysis is that Anglicans are the most negative towards other religious groups in comparison with Catholics in five out of seven cases. This result has subsequently been confirmed in the social cohesion research conducted by Markus (2011). Catholics who have a well-articulated official policy of interreligious respect were found to be the most accepting while the Uniting and Presbyterians were closer to Anglicans. Uniting respondents were the most negative in their responses to Hindus.

Religious identity is clearly a factor in Australian life. Australians are more accepting of some groups than of others, while overall levels of acceptance of religious diversity are increasing, negative attitudes towards Muslims are expressed by nearly one-quarter of Australians. Religious identity is also a predictor variable shaping who is more likely to be accepting and who is not. Catholics were shown to be more accepting than Presbyterians and Uniting, but Anglicans the least welcoming of all.

\section{References}

Appleby, R. Scott. 2000. The Ambivalence of the Sacred: Religion, violence and reconciliation. New York: Rowman \& Littlefield.

Bell, Diane. 2009. 'Aboriginal and Torres Strait Islander religions'. In The Encyclopedia of Religion in Australia, ed. James Jupp. Melbourne: Cambridge University Press.

Bogardus, Emory. 1925. 'Social distance and its origins'. Journal of Applied Sociology 9: 216-26, <http://www.brocku.ca/MeadProject/Bogardus/ Bogardus_1925b.html> accessed 20 September 2008. 
Australia: Identity, Fear and Governance in the 21 st Century

Bogardus, Emory. 1933. 'A social distance scale'. Sociology \& Social Research 17: 265-71.

Bogardus, E. S. 1947. "Measurement of Personal-Group Relations," Sociometry, 10: 4: 306-311

Bouma, Gary. 2006. Australian Soul: Religion and spirituality in the $21^{\text {st }}$ century. Cambridge: Cambridge University Press.

Bouma, Gary and Dixon, Beverly. 1986. The Religious Factor in Australian Life. Melbourne: MARC.

Bouma, Gary, Cahill, Desmond, Delall, Hass and Zwartz, Athalia. 2011. Freedom of Religion and Belief in $21^{\text {st }}$ Century Australia. Sydney: Human Rights and Equal Opportunity Commission.

Bouma, Gary, Pickering, Sharon, Dellal, Hass and Halafoff, Anna. 2006. Managing the Impact of Global Crisis Events on Community Relations in Multicultural Australia: Models and processes. Report to Multicultural Affairs Queensland and Victorian Office of Multicultural Affairs. <http://mp3.news.com.au/ bcm/Multicultural/MAQ_Global_Crisis_bkgrnd_report.pdf $>$

Cahill, Desmond, Bouma, Gary, Dellal, Hass and Leahey, Michael. 2004. Religion, Cultural Diversity and Safeguarding Australia. Canberra: Department of Immigration and Multicultural and Indigenous Affairs.

Carey, Hilary. 1996. Believing in Australia. Sydney: Allen \& Unwin.

Cimino, Richard. 2005. "No God in common": American evangelical discourse on Islam after 9/11'. Review of Religious Research 47: 162-74.

Deen, Hanifa. 2009. The Jihad Seminar: A true story of religious vilification and the law. Perth: University of Western Australia Press.

Dietrich, Sandra, Beck, Michael, Bujantugs, Bujana, Kenzine, Dennis, Matschinger, Herbert and Angermeyer, Matthias. 2004. 'The relationship between public causal beliefs and social distance toward mentally ill people'. Australian and New Zealand Journal of Psychiatry 38: 348-54.

Fletcher, Brian. 2002. 'The Anglican ascendancy: 1788-1835'. In Anglicanism in Australia: A history, ed. B. Kaye. Melbourne: Melbourne University Press.

Hogan, Michael. 1987. The Sectarian Strand: Religion in Australian History. Ringwood VIC: Penguin. 
Human Rights and Equal Opportunity Commission (HREOC). 2004. Isma区listen: national consultations on eliminating prejudice against Arab and Muslim Australians. Report. Sydney: Human Rights and Equal Opportunity Commission.

Hutchinson, Mark. 2009. 'Pentecostals'. In The Encyclopedia of Religion in Australia, ed. James Jupp. Melbourne: Cambridge University Press.

Jones, James. 2008. Scheffe and Tukey Tests. <http://people.richland.edu/james/ lecture/m113/post_anova>, accessed 26 September 2008.

Jupp, James (ed.). 2001. The Australian People. Second edition. Melbourne: Cambridge University Press.

Jupp, James. 2009a. 'Jehovah's Witnesses'. In The Encyclopedia of Religion in Australia, ed. James Jupp. Melbourne: Cambridge University Press.

Jupp, James (ed.). 2009b. The Encyclopedia of Religion in Australia. Melbourne: Cambridge University Press.

Jupp, James, Nieuwenhuysen, John and Dawson, Emma (eds). 2007. Social Cohesion in Australia. Melbourne: Cambridge University Press.

Levi, John. 2006. These are the Names: Jewish lives in Australia 1788-1850. Melbourne: Miegunyah.

Levi, John and Bergman, George. 2002. Australian Genesis: Jewish convicts and settlers 1788-1860. Melbourne: Melbourne University Press.

Markus, Andrew. 2008, 2009, 2010, 2011. Mapping Social Cohesion-The Scanlon Foundation surveys - Summary report. Melbourne: Monash Institute for the Study of Global Movements.

Office of Multicultural Affairs (OMA). 1989. Issues in Multicultural Australia. Canberra: Office of Multicultural Affairs.

Parrillo, Vincent and Donoghue, Christopher. 2005. 'Updating the Bogardus social distance studies: a new national survey'. The Social Science Journal 42: 257-71.

Piggin, Stuart. 2009. 'Evangelical Christianity in Australia'. In The Encyclopedia of Religion in Australia, ed. James Jupp. Melbourne: Cambridge University Press.

SPSS Help. 2008. GLM Post Hoc Comparisons. 
Australia: Identity, Fear and Governance in the 21 st Century

Tamis, Anastasios. 2009. 'Greek Orthodoxy in Australia'. In The Encyclopedia of Religion in Australia, ed. James Jupp. Melbourne: Cambridge University Press.

Thyne, Maree and Lawson, Rob. 2001. 'The design of a social distance scale to be used in the context of tourism'. Asia Pacific Advances in Consumer Research 4: 102-7. 